\title{
Urban revitalization in highly localized squares: A case study of the Historic Centre of Macao
}

AUTHOR(S):

Wang, Yongcheng; Yamaguchi, Keita; Kawasaki, Masashi

\section{CITATION:}

Wang, Yongcheng ... [et al]. Urban revitalization in highly localized squares: A case study of the Historic Centre of Macao. URBAN DESIGN International 2018, 23(1): 34-53

\section{ISSUE DATE:}

2018-02

URL:

http://hdl.handle.net/2433/230346

\section{RIGHT:}

This is a post-peer-review, pre-copyedit version of an article published in 'URBAN DESIGN International'. The final authenticated version is available online at: http://dx.doi.org/10.1057/s41289-016-0009-5; The full-text file will be made open to the public on 01 February 2019 in accordance with publisher's 'Terms and Conditions for Self-Archiving';: この 論文は出版社版でありません。引用の際には出版社版をご確認ご利用ください。; This is not the published version.

Please cite only the published version. 


\title{
Urban revitalization in highly localized squares: A case study of the Historic Centre of Macao
}

\author{
Yongcheng Wang $^{\mathrm{a}, \mathrm{b}, *}$, Keita Yamaguchi ${ }^{\mathrm{a}, \mathrm{c}}$ and Masashi Kawasaki ${ }^{\mathrm{a}, \mathrm{d}}$
}

${ }^{a}$ Department of Civil and Earth Resources Engineering, Graduate School of Engineering, Kyoto University, Kyoto, Japan.

${ }^{\mathrm{b}}$ Blk 303 Jurong East St 32 \#04-90, Singapore 600303, Singapore.

E-mail: wan9.s1m0n@gmail.com

${ }^{c}$ Room 203, Bldg C1, Kyoto University Katsura Campus, Nishikyo Ward, Kyoto 615-8530, Japan.

E-mail: yamaguchi.keita.8m@kyoto-u.ac.jp

${ }^{\mathrm{d}}$ Room 202, Bldg C1, Kyoto University Katsura Campus, Nishikyo Ward, Kyoto 615-8530, Japan.

E-mail: kawasaki.masashi.7s@kyoto-u.ac.jp

${ }^{*}$ Corresponding author.

\begin{abstract}
This paper focuses on Macao's indigenous form of public space - chintei - the historic squares that epitomize the former Portuguese colony and remain a unique feature of the city-state under the rubric of the Special Administrative Region (SAR) of China. With Macao currently experiencing the ambivalence of a cultural enclave versus a global gaming hub, the squares are facing an unprecedented phase of transformation where heritage conservation converges or even collides with redevelopment pressures. Discussions are engaged about the government's stance on preserving and revitalizing the squares, which can be either regarded as residual space or architectural ensemble and project potentiality of urban heritage especially after the inscription of the Historic Centre of Macao on the World Heritage List. Findings from case studies demonstrate that the squares' revitalization is a process of trial and error that continuously redefines them, and their diminished socio-spatial vitality has yet to be revived.
\end{abstract}

URBAN DESIGN International (2016). doi:10.1057/s41289-016-0009-5

Keywords: urban revitalization; heritage conservation; historic centre; squares; Macao

\section{Introduction}

Historic districts undergo change at a faster pace today, and face the challenges of retaining their intrinsic urban character as well as their economic viability during development or redevelopment processes. Governmental efforts to protect historic districts tend to occur in the sequence of preservation, conservation, and revitalization, where concern moves from individual buildings to areas as a whole, and the acceptability of change - which is inevitable for any urban environment - increases (Tiesdell et al, 1996). However, those efforts usually synthesize the three elements when a single period is focused on. More importantly, treating an urban historic area as a whole requires a sensitivity to space and place - a duo that has been extensively discussed in the literature, especially from a perceptual perspective (Tuan, 1977). Rykwert (2002) begins his polemic in The Seduction of Place with a notion "not against the disordered, even chaotic city, but against the anonymous and alienating one," which calls for the recognition of the quasiorganic nature of the city that emerges from incremental place-making activities.

Across the spectrum of revitalization initiatives from visual to functional dimensions, this paper devotes most of its discussion to Macao, one of the two Special Administrative Regions (SARs) at the 
estuary of the Pearl River in Guangdong Province, China. It aims to draw out the implications of the elements of an urban historic setting that appear particularly compelling to preserve (or conserve) in a holistic district-wide approach, yet may go astray in an arbitrary interpretation of revitalization. Macao thrived and prospered as an entrepôt on the "maritime silk road" after it was first settled by the Portuguese in 1557 during the Age of Discovery. It entered a transition period ${ }^{1}$ in 1987 and the Chinese resumed sovereignty in 1999. The peninsular retains its resplendent Portuguese architecture, which serves as a testimony to the Luso-Chinese cultural symbiosis of some four and a half centuries. Walking through the intricate urban fabric in Macao can be a serendipitous experience because of the juxtaposition of Christian churches and Chinese temples, as well as the nonrectangular linkages of roads and streets.

To add to its uniqueness, Macao's urban fabric is punctuated by a series of piazza-like small-scale squares - a type of public space influenced by the Portuguese - with the local name chintei (前地), which literally means "land in the front," as opposed to its generic counterpart kwongcheong (廣場) $)^{2}$. A total of 45 squares (Figure 1) are reviewed in this paper and those identified as historic share the morphological visages as an accompaniment to buildings, or as a "by-product" of the construction or widening of roads (Duncan, 1987). They are characteristically: (1) formed by the re-purposing or conversion of the residual outdoor space outside monuments (churches or temples) or civic buildings; (2) small-scale and usually irregularly shaped; and (3) possessing historical and cultural significance, and a strong sense of place.

The urban construction regime in a city undergoing a socio-political transition - the sovereignty transfer from Portugal to China on December 20, 1999 - tends to be located before and after such a threshold (Edmonds and Yee, 1999), in which "localization" is called for and yet inevitable. Enveloped by the high-rise buildings and casinohotel entertainment facilities which exemplify the intensification endorsed by China's 12th Five-Year Plan (FYP) ${ }^{3}$ 2011-2015, Macao's squares, scattered through the old town, retreat into relative inconspicuousness, compared with the city' image as an international gaming hub, especially after the government two more gambling licenses in 2003 to end the monopoly of Sociedade de Turusmo e Diversões de Macau (STDM). However, the positive effects of Macao's status as a historic and cultural enclave are paramount for urban development from a tourism perspective, which is in line with the following 13th FYP 2016-20 that also emphasizes the diversification of Macao's economy. Although heritage conservation has had roots in Macao since the 1960s, a more holistic approach to conserving and revitalizing the historic centre, of which squares are a critical component, is required to enhance the spirit and sense of place that can be shared by both residents and tourists. What Figueira (1988, p. 21) once pointed out regarding heritage conservation in Macao is still largely applicable:

The effort to make the city aware of its past has been the most important aspect of the struggle ... but the city still lives on, albeit withered, but still retaining the individualistic characteristics which were shaped by the Portuguese ... and which make it unique in the region.

The authors have carried out a comparative review of the squares on Peninsular Macao that focused on incremental changes rather than the impact of infrastructure construction. Regions of the two offshore islands (Taipa and Coloane) which are now connected by the reclaimed Cotai strip housing casino-hotel resorts are excluded since the historic urban fabric is concentrated on Peninsular Macao whereas the pressures exerting from the development in the former are taken as an externality to the conservation of the latter. The review used digital maps as of 2013 published by the Cartography and Cadastre Bureau, Direcção dos Serviços de Cartografia e Cadastro (DSCC) and the Register of Public Roads in Macao SAR published by the Institute for Civic and Municipal Affairs, Instituto para os Assuntos Cívicos e Municipais (IACM) to identify the location, scale, peripheral land use, etc. of the squares in question; information on streetscape improvement projects was sourced from the relevant government agencies, primarily IACM, and heritage designation status was sourced from the Cultural Affairs Bureau, Instituto Cultural (IC). Documents pertinent to the application for World Heritage inscription of "the Historic Centre of Macao" are reviewed to illustrate IC's recognition of squares as a type of cultural heritage prompted by UNESCO and the International Council on Monuments and Sites (ICOMOS), which sets a keynote for IACM's streetscape improvement in 


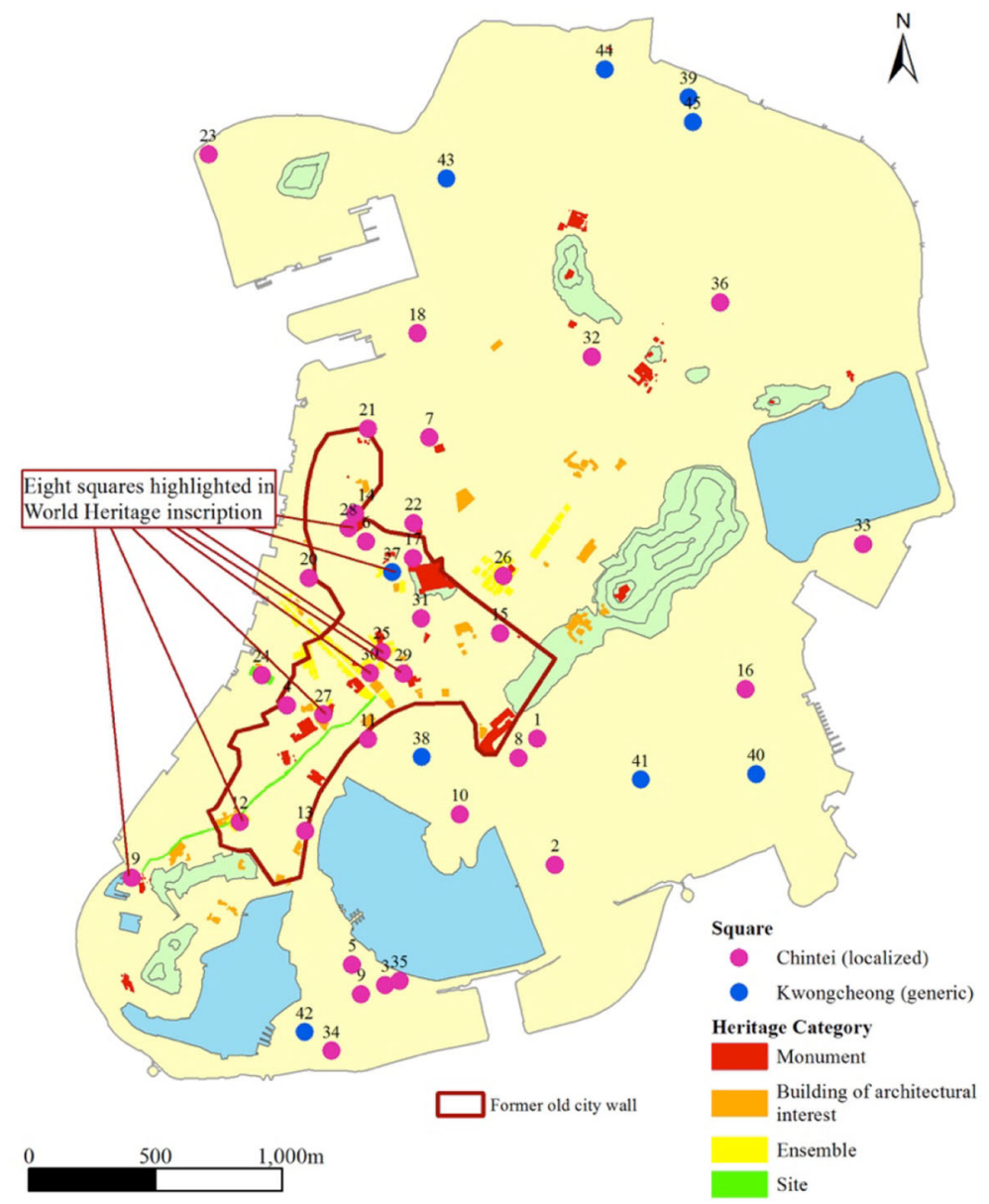

Figure 1: Locations of squares and cultural heritage (natural heritage which are not associated with buildings or squares are excluded) in Macao Peninsula. Red points indicate chintei, while blue ones kwongcheong.

Source: DSCC and IC, edited by the authors.

the historic centre. This has allowed a qualitative evaluation of the correlation between the two axes of square revitalization, functionality and sense of place.

The interaction, or occasionally the collision, of the two axes is further illuminated by case studies conducted of three small-scale piazza-like squares in the Historic Centre of Macao Peninsula, supplemented by field trips and interviews with IACM officials in 2013. The authors have identified an approach that capitalizes on the cultural value of the open space of local squares, associates with the surrounding built environment to enhance the image of the historic centre, and creates a visually striking network with amenities provided for both residents and tourists, which is pragmatic in the case of Macao and implies its applicability to other historic districts facing a similar variety of development/redevelopment pressures.

\section{Chintei, a Highly Localized Form of Square}

\section{Nomenclature of squares in Macao}

Some public spaces invariably evoke a collective memory or a particular kind of perception shared by the inhabitants in the enclave, succinctly expressed in the term "sense of place" in Relph's dialectical work Place and Placelessness (1976). Their names reveal, to a greater or lesser extent, their historic or cultural significance beyond a merely indicative reference. This activation of place memory does not confine itself to insiders, but reaches out to outsiders when their "historical imagination" is called on by "inventive signing and mapping," etc. (Hayden, 1995).

The practice of naming streets and squares in Macao reflects the Sino-Portuguese symbiosis cultivated over several centuries, physically manifested in the blue and white street nameplates 


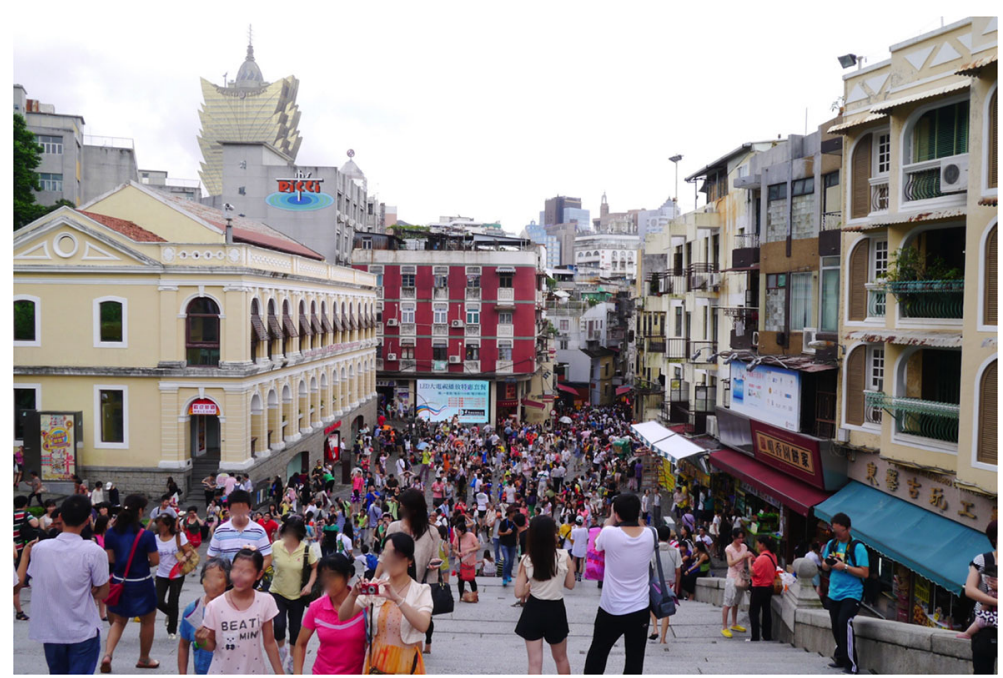

Figure 2: Company of Jesus Square, looking from up on the stairs toward the ruins of St. Paul's Cathedral. One of the most popular sightseeing spots in Macao.

Source: Photo by the authors.

made of azulejo, a traditional Portuguese ceramic tilework. There is a more comprehensive account of this distinctive inscription of Macao's urban fabric in a linguistic landscape in Huang's research, in which he summarizes the names used, examines the differences in meaning between the Portuguese names and their Chinese counterparts (2007), and proposes, for instance, a cultural explanation of rotunda roundabouts as a representation of harmony (2012).

Such an abstraction of place may vary from individual to individual, but it remains the case that the name of a place affects the way it is perceived, and the connection between a square's name and its spatial configuration is a clue to crucial historical and cultural associations. In a similar fashion to the three Portuguese words (praceta, praça, and largo) used to name squares, with their subtle references to their configuration $(\mathrm{Xu}, 2009)$, there is also more than one variation in the Chinese context: chintei is more historic or local, and kwongcheong is more generic or modern. In Macao, the local name of the square is emphasized because, in addition to shape and size, implications of historic continuity are embedded within it, so a place can be perceived as meaningful and rich in a cultural context, whether explicitly or subliminally. Despite the fact that the lineage from historic to modern squares is becoming unclear, chintei squares are densely situated in the central part of Peninsular Macao. Furthermore, with academic attention already drawn to the nomenclature of Macao's streets, chintei are used in this research as an indicative concept for a broader perspective on urban heritage conservation and revitalization.

\section{Squares in the Historic Centre of Macao}

The city walls have become untraceable as a result of their intermittent construction and demolition during times of political and military tension between the Portuguese and Chinese governments (Tan, 2009). Significant land reclamation since the late 19th century has resulted in drastic changes to the coastline. In relation to land reclamation, Xue (2013) elaborates on the period when Macao ceased to be a true colony and entered the modern era of urban construction and regional planning practices. Even though the history or anecdotes relating to a square may not be well-known, accurate knowledge about whether it was located in the old city is an indication of its historic nature, and this helps cultivate public awareness and participation in locality-sensitive urban planning.

Based on the approximate boundaries of the city walls (Huang, 2002), there are fifteen squares in the old city of Macao (Figure 1). All of them are called chintei in Chinese, except the Company of Jesus Square (Figure 2), which fronts the ruins of St. Paul's Cathedral. However, it is close to the typical historic square in Macao because of its geographical location in the centre of the old city and its medium scale. In fact, the Company of Jesus Square was formerly called "Largo de S. Paulo" (Nuñez, 1999, p. 41). Taken together, the squares provide a set of 
invaluable examples of the preservation of the unique aspects of Macao's urban fabric.

What differentiates historic squares from the newly built ones is their rich architectural context. As discussed above, the traditions and customs that the individual monuments or architectural ensembles call to mind invariably influence the perception of such historic urban squares. Lin (2004) identifies three types of squares, based on the relationship between the open space and its setting. They are: (1) a setting with only one building, the defining structure, as the focal point; (2) a setting with two or more similarly prominent buildings, for example, St. Augustine's Square; and (3) a nonfocal setting without a defining structure, such as Lilau Square or Largo da Companhia. Although Lin observes that the straightforward square setting with only one defining element is being eradicated in the old city, squares such as Senado Square and St. Anthony's Square can still be included in this category because of the civic buildings and religious monuments that surround them. Table 1 lists the squares recorded in the Register of Public Roads in Macao SAR that fit the criteria above and are part of the road network, although they are more pedestrian-oriented. The ambiguity of boundaries or indefiniteness of the linear structure of squares is a product of their proximity to the surrounding areas, and the historic squares blend easily into an urban area with its various businesses and facilities. This irregularity of form is "unplanned," but it has evolved to be part of the square's intrinsic identity, which differentiates it from others on a larger scale but with less sense of place.

The semi-independence or interdependence between squares and their urban context characterizes the Historic Centre of Macao, and their transitional function as urban nodes can be effectively demonstrated through a comparison with two other types of Macao open space, beco and patio, i.e., narrow alleys and cul-de-sacs. These are discussed in terms of their continuity with the outer street network, and homogeneity in relation to width, height, and the number of levels of the buildings (Kato, 2003; Matsuda, 2005). Most of the squares in a mixed-use setting possess a higher level of continuity than a cul-de-sac, and street connectivity, façade transition, peripheral use, and topography are the major attributes used to analyze the continuity of squares (Korenaga, 2003, 2006). This analysis of the open space assists in identifying the quintessential attributes that should not be altered arbitrarily during maintenance and redevelopment, from which the chintei concept transpires. This discussion has also identified the fact that each particular square has its own history or stories. Therefore, this discussion has illuminated the internal paradox that midscale categorization is restricted by too many place-specific conditions and lacks applicability in the revitalization process.

\section{The Emergence of Squares in Urban Heritage Conservation}

\section{Public space in a tourism boom}

As the titles "Las Vegas in the East" and "Monte Carlo of the Orient" suggest, the city-state of Macao is highlighted on the international stage most often as a gaming hub. Drastically changing the skyline and cityscape, the mega-facilities that surround the historic core of Macao make a legitimate statement of their importance from a contemporary perspective. Simpson (2013) elaborates on the relationship between consumerism and architectural form, using the glass curtain wall as an indication of the city's status as a socialist capitalism exclave, "an interstitial tourist city paradoxically both inside and outside the PRC." This status to some extent creates a competitive relationship between residents and visitors over public space, which has already sparked negative attitudes toward the surge in tourism, especially from the mainland, and worries about the city's capacity (Lotus TV, 2013, 2014). On the other hand, as diversification within the tourism industry is also important, for example, through the compatibility of a gaming destination and cultural heritage (So, 2012), an end-user balance between residents and tourists is called for in the redevelopment of Macao's cultural core. Otherwise, "if the decision from the government emphasizes tourism development too much, which can be seen by excessive open space development," claims Pimonsthean (2004), "...the area will lose its charm and existing fabric."

The promotion of cultural tourism (Zhang et al, 2011) has begun to take a more prominent position in the conservation and revitalization of the old town, urban fabric of which is threatened by gaming industry development. In the decade from 2002 , streets and squares were revamped to enhance their visual character and amenities, under the rubric of "maximizing the effect of 
望: Wang et al

Table 1: Categorization of Macao's localized squares

\begin{tabular}{llll}
\hline Square & Ref & Area \\
no. & $\left(\mathrm{m}^{2}\right)$
\end{tabular}$\quad$ Adjacent heritage/landmark Recent improvement project nearby

Type 1: A setting with only one building as the focal point (church, temple or civic building),namely the defining structure

25 de Abril, Praceta

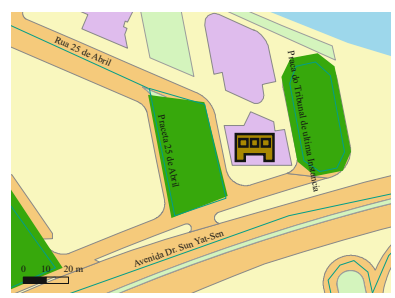

Mercado Municipal, Largo do

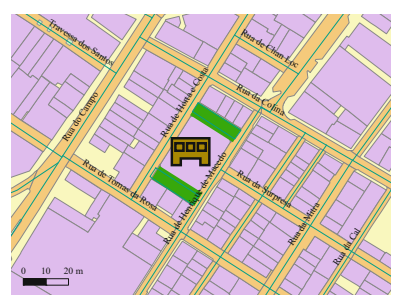

Pagode da Barra, Largo do

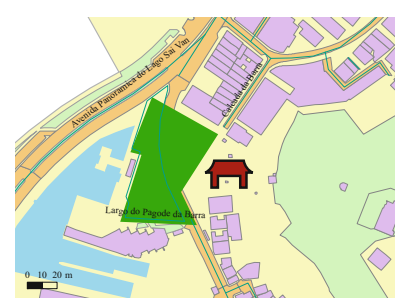

Pagode do Bazar, Largo do

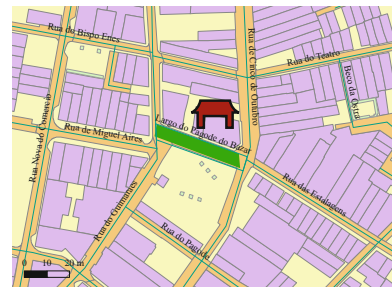

Pao Cong Mio, Largo do

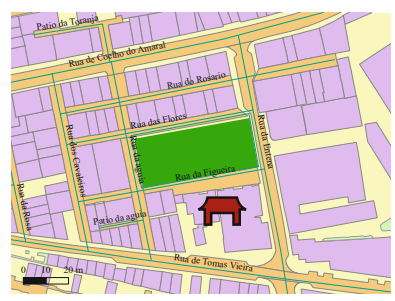

3

1230 Building of the Superior Courts

15

$300 \quad$ Market of Horta da Mitra

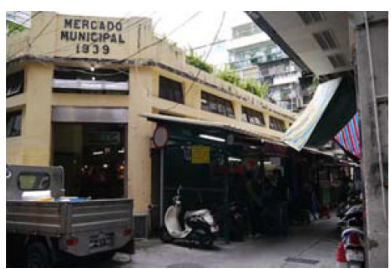

19

3200 A-Ma Temple Rua Direita

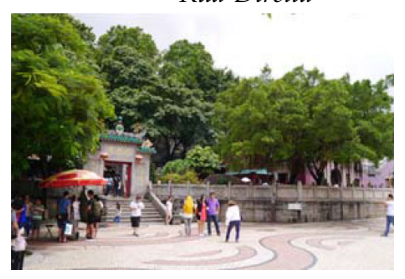

20

220

Bazar Temple

22

1140 Pao Cong Temple
Repaving with bricks on the sidewalk of Avenida Dr. Sun Yat-Sen (2002)

Construction of refuse chamber (2007)
Sidewalk widening in Rua do Miguel Aires (2008). sidewalk construction along Rua e Cinco de Outobro $(2002,2004)$

Sidewalk beautification in Rua de Coelho do Amaral (2009) 
Table 1 continued

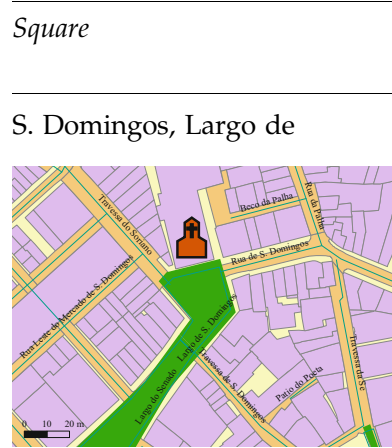

S. Lázaro, Adro de

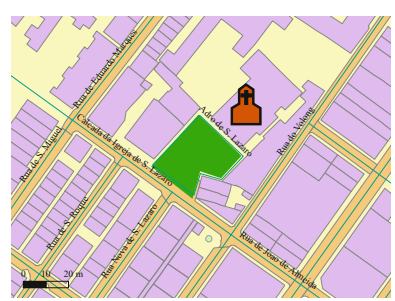

Santo António, Largo de

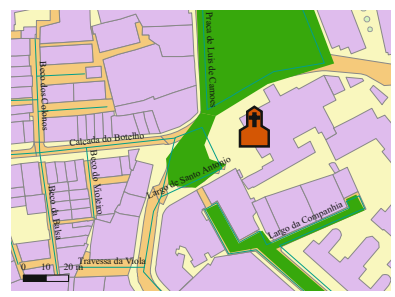

Sé, Largo da

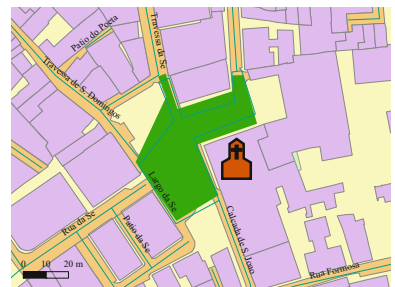

(also see Figure 8)

Companhia de Jesus, Largo da

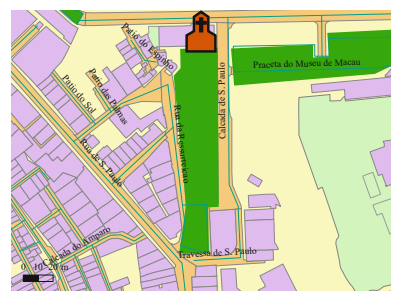

(also see Figure 2)
Ref Area Adjacent heritage/landmark

no. $\left(m^{2}\right)$

$25790 \quad$ St. Dominic's Church Group of buildings along San Ma Lo

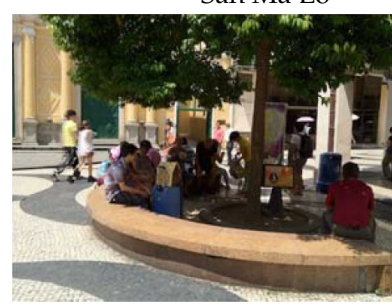

26

700

St. Lazarus Church Group of buildings near St. Lazarus Church

28 480

St. Anthony's Church

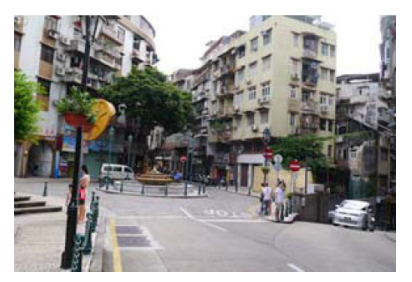

29

1640

\section{Cathedral \\ Buildings at 1, 3, 5 \\ Cathedral Square}

Ruins of St Paul's Cathedral Na Tcha Temple Section of the Old City Walls Buildings at 4, 6 Jesus Company Square Group of buildings at St. Paul's Street Group of buildings at Passion Lane
Recent improvement project nearby

Repaving of Senado Square (2003), near Cathedral Square (2004) and peripheral streets along San Ma Lo (2004)

Repaving of Rua de Luís Joao Baptista

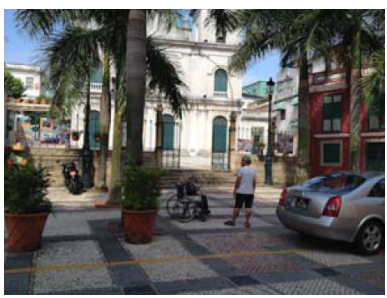

Reorganization of Camoes Square (2008) Sidewalk beautification in St. Anthony's Square (2006) and Rua do Coelho do Amaral (2009)

Beautification of Cathedral Square and peripheral streets (2004-2009)

Rearrangement of the roads and sidewalks in Calcada de S. Paulo (2009) 
些: Wang et al

Table 1 continued

\begin{tabular}{llll}
\hline Square & $\begin{array}{l}\text { Ref } \\
\text { no. }\end{array}$ & $\begin{array}{l}\text { Area } \\
\left(\mathrm{m}^{2}\right)\end{array}$
\end{tabular}$\quad$ Adjacent heritage/landmark Recent improvement project nearby

Type 2: A setting with two or more buildings prominence of which is of the same degree

Luís de Camões, Praça de

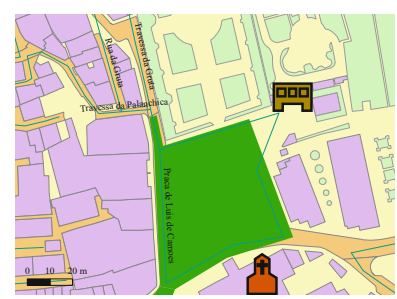

(also see Figure 10)

Santo Agostinho, Largo de

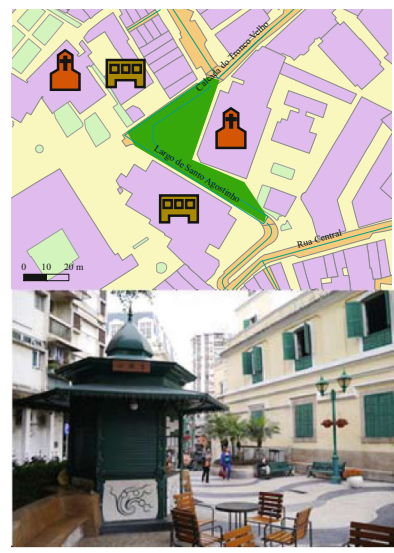

Senado, Largo do

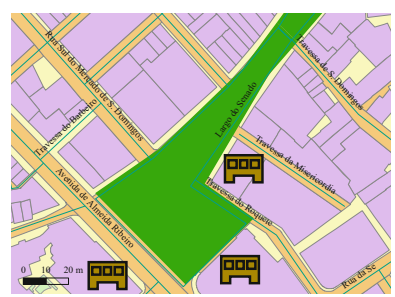

(also see Figure 4)

Type 3: A nonfocal setting without a defining structure

Aquino, Largo do

4

300

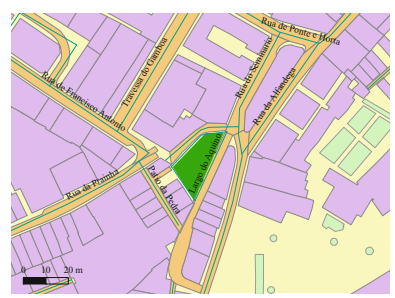

Reorganization of Camoes Square (2008)

Casa Garden

St. Anthony's Church

27

1170 Sir Robert Ho Tung Library St. Augustine's Church St. Joseph's Seminary and Church Group of buildings at St. Augustine's Square
30

3250 "Leal Senado" Building Holy House of Mercy

Central Post Office

Group of buildings along San Ma Lo

\author{
Repaving and sidewalk \\ construction near St. Augustine's \\ Square (2005)
}

Repaving of Senado Square (2003)

Beautification along San Ma Lo (2005)
Sidewalk construction on Rua da Alfandega (2003) 
Table 1 continued

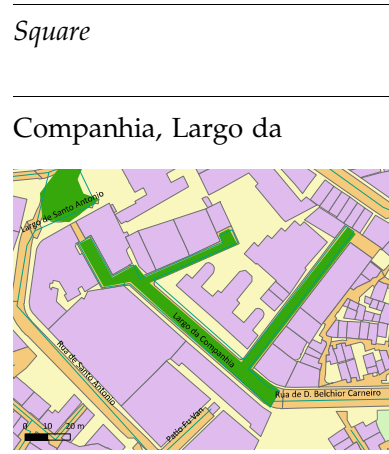

Ref Area Adjacent heritage/landmark no. $\quad\left(m^{2}\right)$

6

1250

St. Anthony's Church

Cordoaria, Largo da

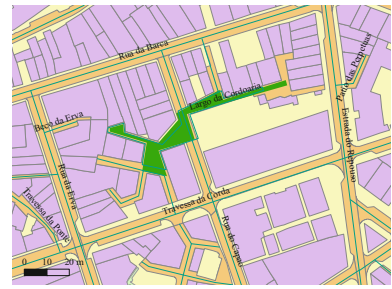

Lilau, Largo do

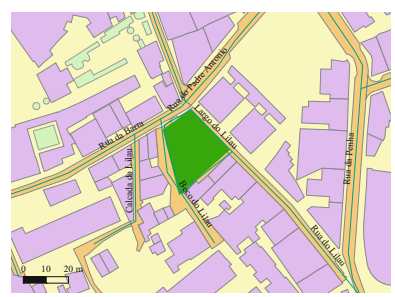

(also see Figure 6)

Lobo de Ávila, Praça de

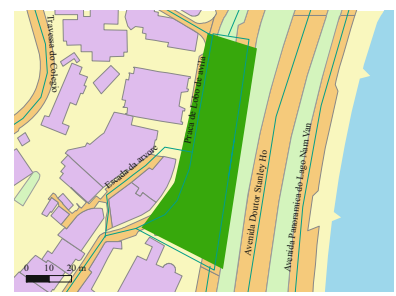

Ponte e Horta, Praça de

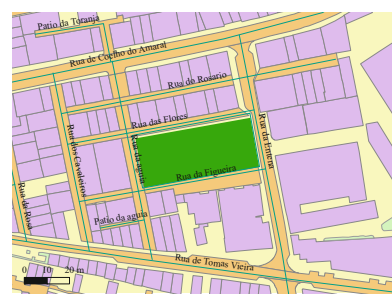

7

420 Cine-Teatro "Alegria

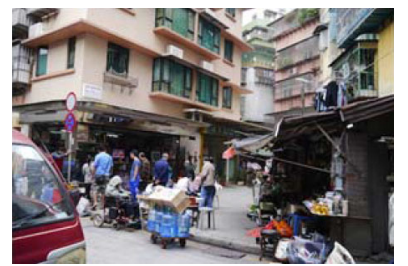

12

590

Mandarin's House

Group of buildings at Lilau

Square and Lilau Alley
13

2600 Ricci School Jardines House

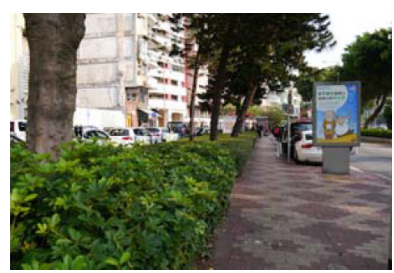

24

3000 Building at "Ponte e Horte" Square and Lorchas Road (Opium House)

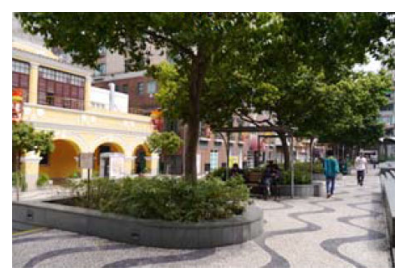

Recent improvement project nearby

Street beautification of Rua de D. Balchior Carneiro (2006), near St. Anthony's Square (2008)

Repaving of Travessa do Capao (2005) and reorganization of nearby roads (2009)

Beautification of Lilau Square and Rua Direita (2009)

Repaving of Avenida da Praia Grande (2002) Garbage chamber (2008)

Sidewalk construction on Rua do Bocage 
Table 1 continued

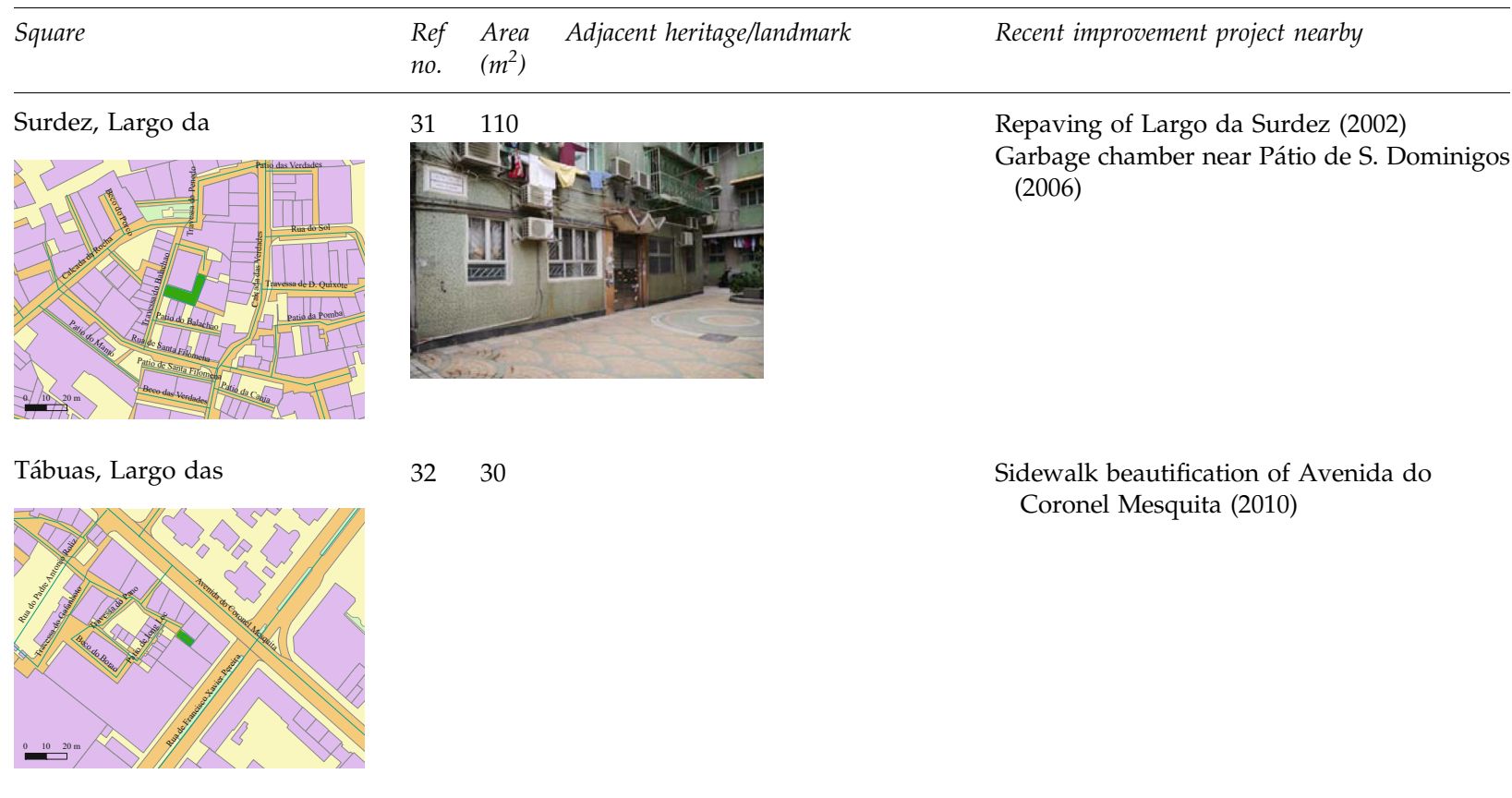

World Heritage." ${ }^{\prime 4}$ From 2012 onward, more cultural significance has been revived through the design and promotion of Cultural Trails, initiated by a symposium dedicated to the streets of Macao and followed by a series of events such as Street Ambassador. These initiatives, though generated in part by the need for the diversion of high pedestrian flows from key attractions to peripheral areas, reflect a shift in mindset to retaining what is historically and culturally intrinsic to the urban fabric. This chapter discusses an exemplary change in the official stance on the potentiality of Macao's squares during the application for inscription on the UNESCO World Heritage List.

\section{From "historic monuments" to "historic centre": Squares as a type of cultural heritage}

As the principles of the Washington Charter suggest, qualities of historic districts such as "relationships between buildings and green and open spaces" and "the various functions that ... has acquired over time" in a city area (ICOMOS, 1987) are to be preserved. There may not be a clear answer to the seemingly metaphysical question whether a square is just an auxiliary part of a building or an indispensable part of an urban setting. The duality of Macao's urban squares is visible in the application process for UNESCO World Heritage, initiated in 2002 , and successfully concluded with inscription on the List in 2005. The justification for Macao's historic centre comes from several criteria such as the unique Chinese-Portuguese political environment, its evangelical and trading functions, and other cultural and scientific influences. Macao's urban fabric was generated in an East-meets-West fusion and is "represented in the historical route, with a series of urban spaces and architectural ensembles, that links the ancient Chinese port with the Portuguese city" (UNESCO, 2005, p. 134).

During the early stages of the World Heritage application, the original concept for nomination was "the Historic Monuments of Macao," which consist of twelve monuments and architectural sites (IC, 2001; Macao SAR, 2004). Less emphasis was laid on the idea of a historic district, which included both architectural ensembles and urban spaces, until the ICOMOS mission's visit to Macao. Their evaluation report suggested the nomination concept be changed from "the Historic Monuments of Macao" to "the Historic Centre of Macao." The act of enriching the selected monuments with the addition of squares created a more comprehensive notion of the urban heritage, and appeared to be an expedient move for the application. Nevertheless, the recognition of the distinctiveness of Macao's squares is of paramount importance because it reinforces a holistic approach to urban conservation.

The eight registered squares, roughly from the south to the north, are Barra Square, Lilau Square, St. Augustine's Square, Senado Square, Cathedral 


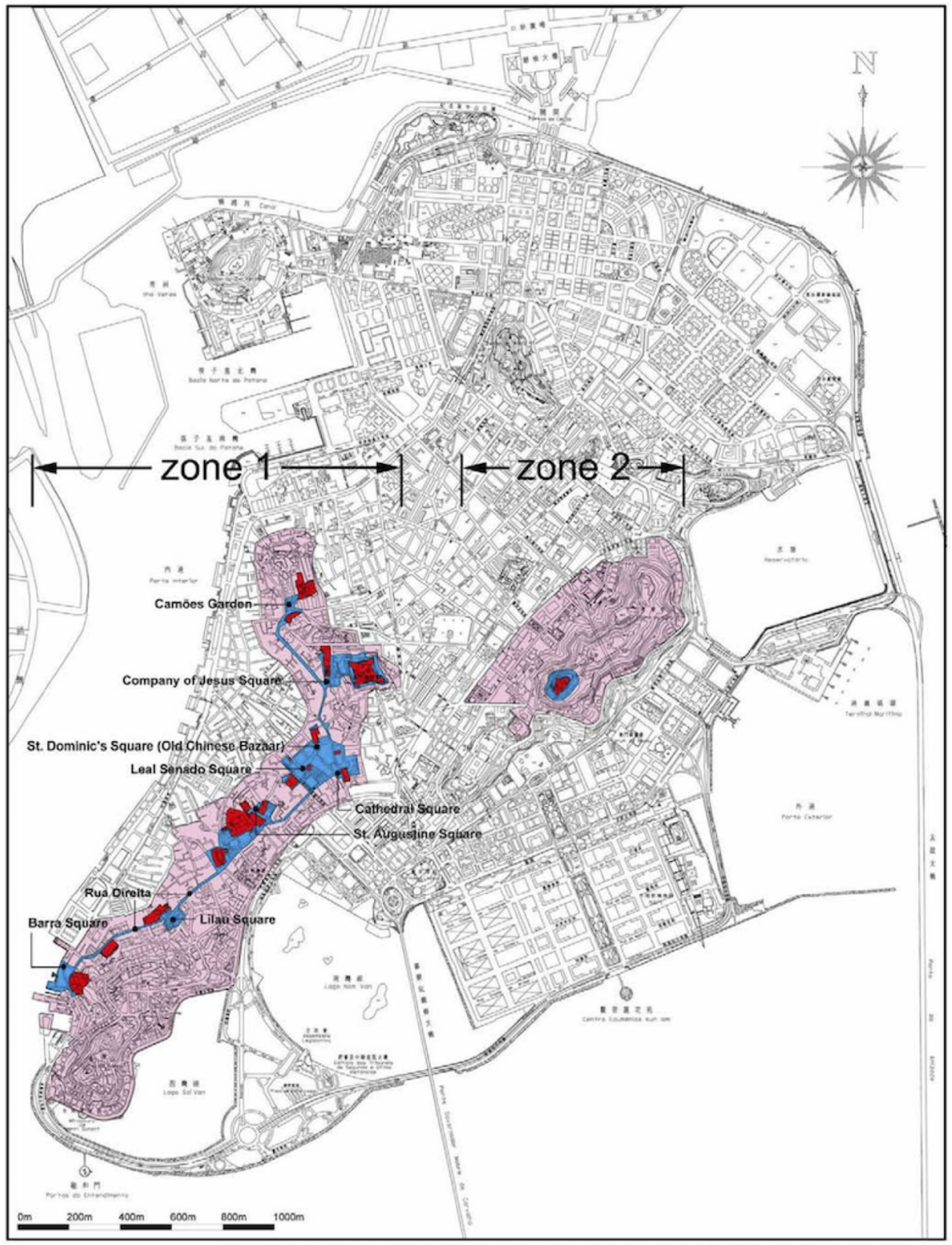

PROTECTED BUILDINGS, PROTECTED AREAS AND BUFFER ZONES

LEGEND:

PLAN DOCUMENT No. 02

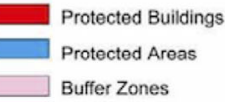

Figure 3: Protected buildings (red), protected areas (blue), and their buffer zones (pink) of the Historic Centre of Macao proposed at the time of UNESCO World Heritage application. The protected area of Zone 1 is a narrow strip of land running

Square, St. Dominic's Square, Company of Jesus Square, and Camões Square. Linking the squares and the monuments is the backbone of the historic centre, Rua Direita (literally "straight street"), formed by Rua da Barra, Rua do Padre António, and Rua Central. It is an urban inheritance from the from north to south ( $3.47 \mathrm{ha}$ ), while Zone 2 is the site of Guia Fortress with the Chapel and the Lighthouse (0.24 ha). Source: Macao SAR (2004).

Renaissance, which displays Portuguese urban traits and intermittent breaking corners of which provide geometric irregularities or "breathable spaces" (Tong, 2005).

The eight squares were added to the number of registered heritage properties. In the supplementary 
document submitted to UNESCO, an action plan incorporating conservation of the built environment and visitor management was put forward to strengthen the concept of the "historic centre" and enhance the awareness of government agencies that heritage conservation must be a collaborative effort (Macao SAR, 2005).

As a result of the adjustment to the application, the two cores zones proposed for the nomination were enlarged, as were their buffer zones (Figure 3). The rationale behind the designation of buffer zones, which have less strict regulations over urban development than the peripheral areas of Macao Peninsula, is to emphasize "the most significant topographic features of Macao's original natural landscape landmarks (Barra Hill, Mount Hill and Guia Hill)," and to acknowledge "the importance of the city's primary streets and public spaces in linking individual buildings within a consistent urban environment" (ICOMOS, 2005). However, preliminary concepts without the enforcement of relevant regulations, and unclear differentiation of heritage management in core zones and buffer zones, may result in inadequate control of urban development, which may greatly impede the conservation of the Historic Centre with its authenticity and integrity intact.

A conservation policy that allows incremental improvements rather than prohibition of any modification to the existing structure or use should occur in tandem with World Heritage inscription. Squares are more susceptible to change because they may be regarded simply as part of the street network, where a firm historic reference may not always be necessary. Macao's first officially issued list of protected properties in 1976 included squares, but their designation in the subsequent addenda and corrigenda reveals their fluctuating identity. The squares attached to St. Joseph's Seminary and the ruins of St. Paul's Cathedral appear in the category of "properties with historic value," while Lilau Street and Square, St. Augustine's Square, Senado Square, and Cathedral Square are in the category of "urban setting that is representative of Macao's cultural heritage ${ }^{\prime \prime}$. After several revisions, the number of listed properties in Peninsular Macao increased from 78 to 102 in 1992. St. Lazarus Square was added, and St. Lawrence Square was re-assigned to the category of "monument." Lilau Square's inscription also underwent a minor change to "Lilau Square and Beco" in place of "Lilau Square and Street." Furthermore, St. Lawrence Square was moved from "natural habitat" to "monument" as "St. Lawrence Church and Square." ${ }^{\prime \prime}$ These instances of the squares' unstable official status illustrate their ambiguous identity, which is intertwined with the insoluble difficulty of their demarcation. The square as a place in a socio-spatial context has been established, but the question of what exactly such a historic square is remains unanswered and creates flexibility in their conservation and revitalization, which is further discussed in the case studies in the following chapter.

\section{The fading distinctiveness of squares in urban planning}

Conflicts in Macao between the government and the public over heritage conservation have gained momentum in recent years, especially in relation to the broader context in which cultural heritage is defined and perceived. Similar events are studied in Tan's research (2011), which untangles the
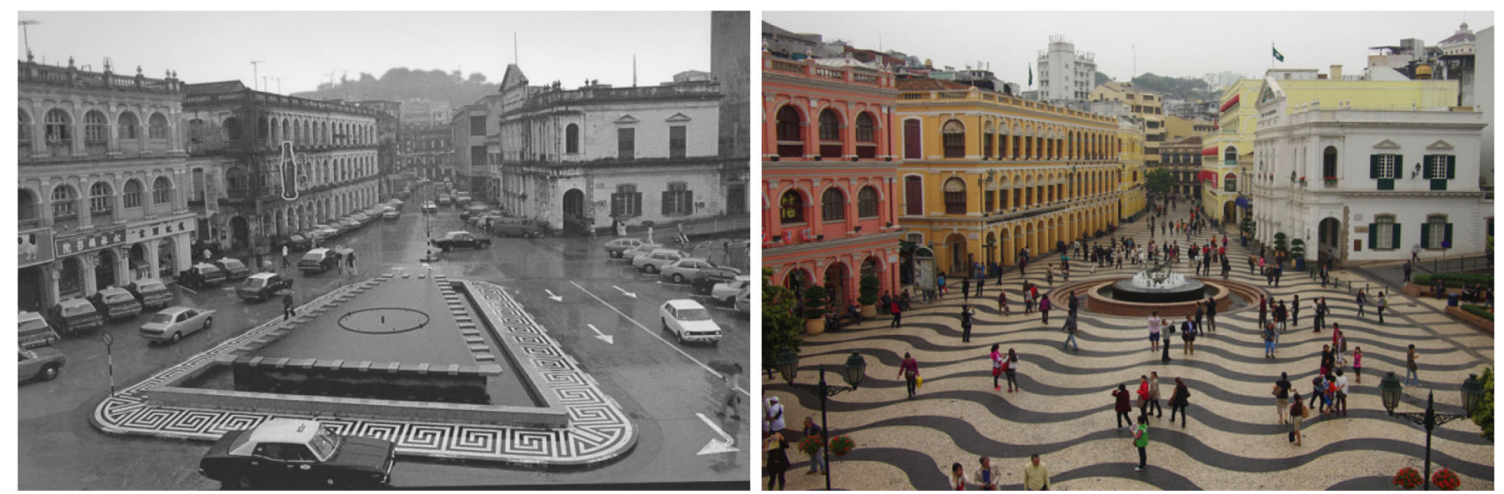

Figure 4: Left Senado Square in the 1970s, better known as "the Fountain" among locals (Source: Li, 2007). Right Senado Square redeveloped as a pedestrian area, nonetheless the IACM building still being dissected by the main road "San Ma Lo" Avenida de Almeida Ribeiro.

Source: photo by the authors. 


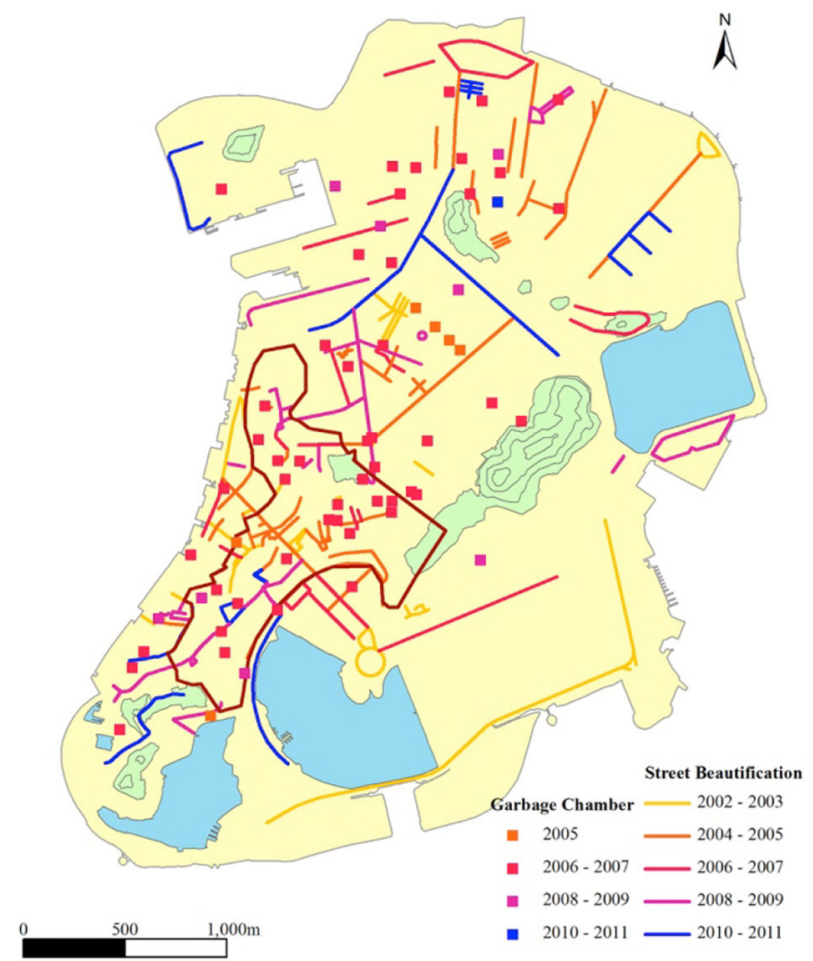

Figure 5: Concurrent progress of street beautification and garbage chamber installation in Macao Peninsula. Source: DSCC and IACM (2013a, b, c, d, 2015), edited by the authors.

interaction among the various parties, for example, in the proposed redevelopment schemes for old buildings such as the wet market in the Praia do Manduco area, or the "Blue House" that houses the Social Welfare Bureau. Some buildings in poor condition have been torn down, for example, an old three-storey Art Deco building that was the landmark in Rua da Praia do Manduco (Lou, 2013).

The town planning function is the responsibility of the Land, Public Works and Transport Bureau, Direcção dos Serviços de Solos, Obras Públicas e Transporte (DSSOPT). In contrast with the volatile approach of DSSOPT, maintenance and improvement in the central area and new reclaimed areas, which are conducted on a much smaller scale, are taken care of by IACM. In the central areas of Peninsular Macao, where the agglomeration of smaller plots into a large one is difficult due to complicated ownership issues, squares with irregular geometry and comfortable human scale manage to survive in the intricate urban fabric. It is the responsibility of IACM to refurbish these public spaces to make them more attractive and to upgrade physical utilities such as pavement and drainage. The former activity generates the most visually prominent changes in the historic centre, exemplified by the transformation of Senado
Square in 1993 through pedestrianization and repaving (Figure 4). The black-and-white cobblestone pavement, with its wavy pattern and marine-related motifs, has subsequently been laid in surrounding areas, creating a stronger sense of walkability and accessibility.

A further series of efforts in the beautification of public space and cityscape in the central areas was initiated in 2002, following Macao's announcement in 2001 of the attempt to apply for UNESCO World Heritage registration, under a "point, line, area" principle with a clear focus on tourist dispersion. In contrast to the several must-sees for tourists such as the ruins of St. Paul's and Senado Square, tourists rarely visited the nearby districts, due to their lack of visibility and accessibility (Va Kio Daily, 2009). The beautification initiatives that IACM carried out from 2002 to 2011, strengthened the Portuguese image of pedestrian infrastructure. In contrast, another need of residents, garbage disposal, is being better catered for in this series of efforts. Garbage containers inevitably occupy the same space in such a condensed area (Figure 5), and this sheds light on the reality of beautification where concurrent functional upgrades are necessary and the two objectives (functionality and beautification) may not be compatible. 


\section{Challenges of Contextual Interpretation Through Functional Upgrading}

The historic squares in Peninsular Macao have their cultural identity entrenched in their local naming, serving as spatial punctuation in the unique urban fabric in the Historic Centre of Macao. Nevertheless, compared with the predominance of the individual monuments, squares of such equally significant cultural qualities did not receive much attention until recently owing to the World Heritage initiative that called for a holistic approach for heritage conservation and urban revitalization. What set an example for the improvements of urban spaces are the three pilot beautification projects - Lilau Square (and the streets from Barra Square and St. Augustine Square), Cathedral Square, and Camoes Square (the proceedings and documents for which were provided for review during the author's research visit in August 2013 to the Department of Cultural Heritage in the Bureau of Culture, Macao SAR). Interviews with then IACM officer Francisco Vizeu Pinheiro also provided important insights.

\section{Lilau Square}

It is believed there used to be a well at the location of the first Portuguese settlement, hence the name Lilau (Li, 2006). The critical location of Lilau Square demonstrates yet another element of its uniqueness in Macao's urban fabric. Despite Among the narrow winding lanes is the identifiable main street, along which some of the prominent monuments and stately houses are located. Yan points out that Rua Direita is a manifestation of Macao's early urban construction, which followed the natural undulating topography while showing respect for churches. He describes the walking experience as "a grand urban orchestra for pedestrians" (2006, pp. 104-112). Starting from the Chinese counterpart of spiritual testimony to this maritime city, A-Ma Temple at the southern end, the streetscape soon changes into a rich mixture of the two cultures, e.g., the Moorish Barracks perched on Calçada da Barra, or the Mandarin's House in Travessa de António da Silva. At the halfway point in the sequence of meandering architecture Lilau Square, a small urban square of about $580 \mathrm{~m}^{2}$, appears as a sudden punctuation. The relatively small-scale square plays an important role in enriching the urban fabric because of its critical location in the old town and its proximity to the surrounding buildings.

According to an on-the-spot survey about what is liked or disliked about the squares, most of the interviewees, including locals and tourists, appreciate Lilau Square's "quietness," "photographic attractiveness," and "Portuguese-Chinese mix of cultures" $^{\prime 7}$ (Pinheiro and Wan, 2007). The conceptualization of a place based on historic references may seem rigid and overly-logical, but the more vernacular opinion shared by passers-by, the actual users of such a public space, inevitably shows a significant discrepancy with the official approach, with their judgement depending on, for example, whether it looks good in a snapshot.
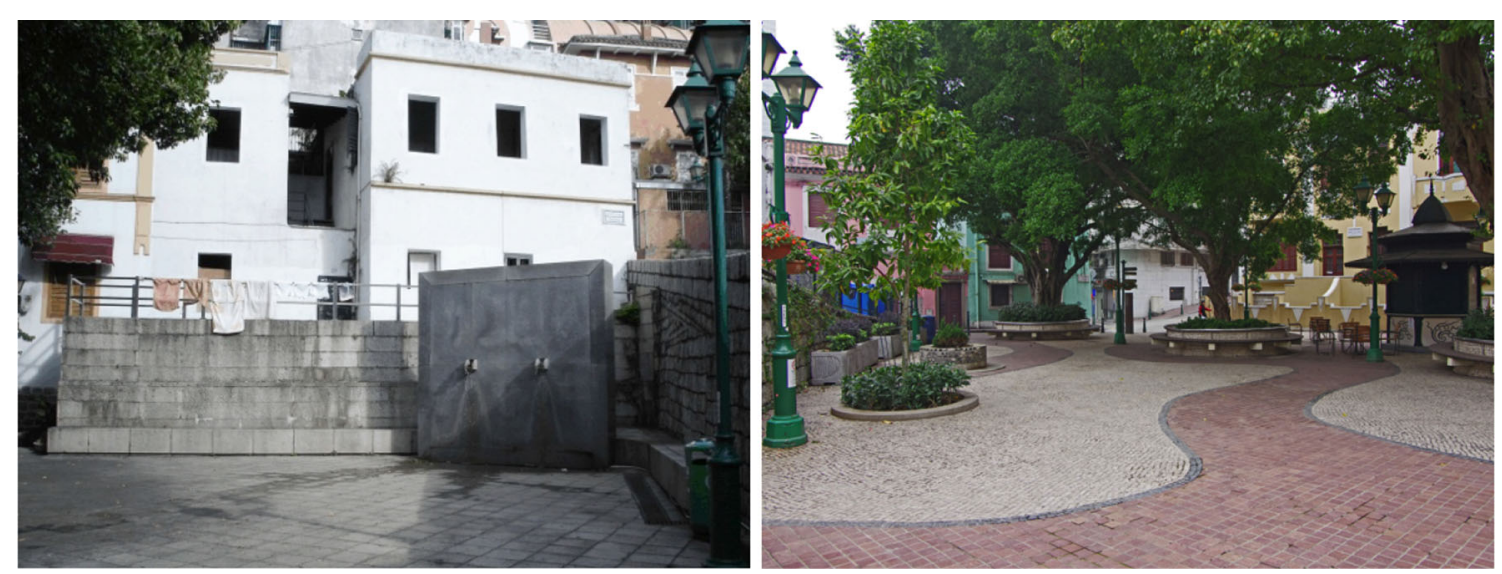

Figure 6: Left: Fountain with a stone plate design in Lilau Square (2007), which draws reference on its story of origin. Nonetheless, what turns out to be water seepage diminishes the attractiveness of this little square. Photo courtesy of Pinheiro. Right: Controversial stone plate is removed, and a vending stall is introduced to the cobblestone-paved square (2012).

Source: Photo by the authors. 


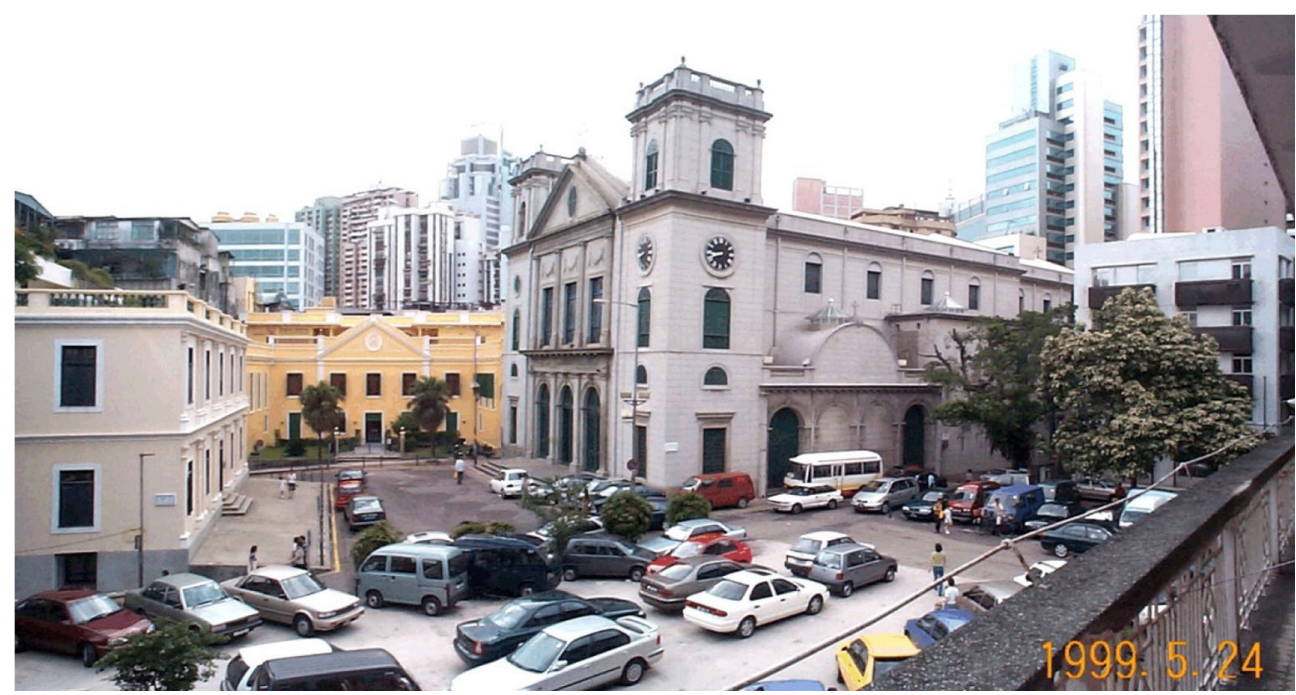

Figure 7: Cathedral Square, most of its area being occupied by car parking (1999).

Source: Photo courtesy of Pinheiro.

Government-led efforts to beautify the historic square followed a recurrent pattern. Renovation was carried out in 1997. However, the installation of a stone plate with water flowing from it (Figure 6, left) received public criticism, despite the original design intention to make it reminiscent of the original spring. The public's opinion was that it was an inauspicious gravestone-like structure, unsuitable for such a communal place of everyday activity (Macao Today, 2009).

The beautification effort of 2009 aimed to restore the original urban character mainly through cobblestone repaving and replacement of the criticized stone plate.

The introduction of the vending stall (Figure 6, right) reflects the approach IACM takes to the conservation and revitalization of such open spaces without adversely affecting the existing urban setting. The interconnection between the periphery and the open space per se adds to the difficulty of perceiving the inherent characteristics of such a place, which may not be a self-evident process, but may exert a substantial influence on the results of conservation and revitalization, especially in such a socio-spatial environment.

\section{Cathedral Square}

Cathedral Square (Largo da Sé), as its name suggests, is located near Macao Cathedral, and is in the shape of an irregular rectangle. The Cathedral, the focus point in the square, was originally built in 1622. It was restored twice, in 1780 and
1836. The current appearance is the design of a local architect, Tomas d'Aquino. ${ }^{8}$

In late 1980s, the Macao Portuguese Government proposed a redevelopment project to convert part of the parking space in the square to public leisure use, and to add an outdoor colonnade as a classic ornamental structure. However, the project was not implemented, and until a second initiative to redevelop Cathedral Square was implemented in 2004, most of the open space in front of the Cathedral remained as parking places (Figure 7). Although not all parking has been eliminated, a successful effort has been made to reclaim an open space for the public.

In 2004, the majority of the area around the Cathedral was used as parking spaces for cars and motorcycles. Given that this scenic spot near Senado Square needed to be more resident- and touristfriendly, the IACM decided to renovate Cathedral Square. DSSOPT and IC played an advisory role in the design process, reviewing the overall plan and making detailed suggestions on specific designs.

In a memorandum about Cathedral Square, DSSOPT was concerned about the decrease of parking provision. In this project, more than half of the 26 parking spaces, plus four for reserved use, was cut down to 13, and thus Cathedral Square might not accommodate parking needs in this area. Other design considerations included the potential narrowing of streets by the enlargement of square space, and appropriate parking provision.

On the other hand, IC endorsed the idea of integrating Senado Square, St. Dominic's Square, and the Ruins of St. Paul's through the 


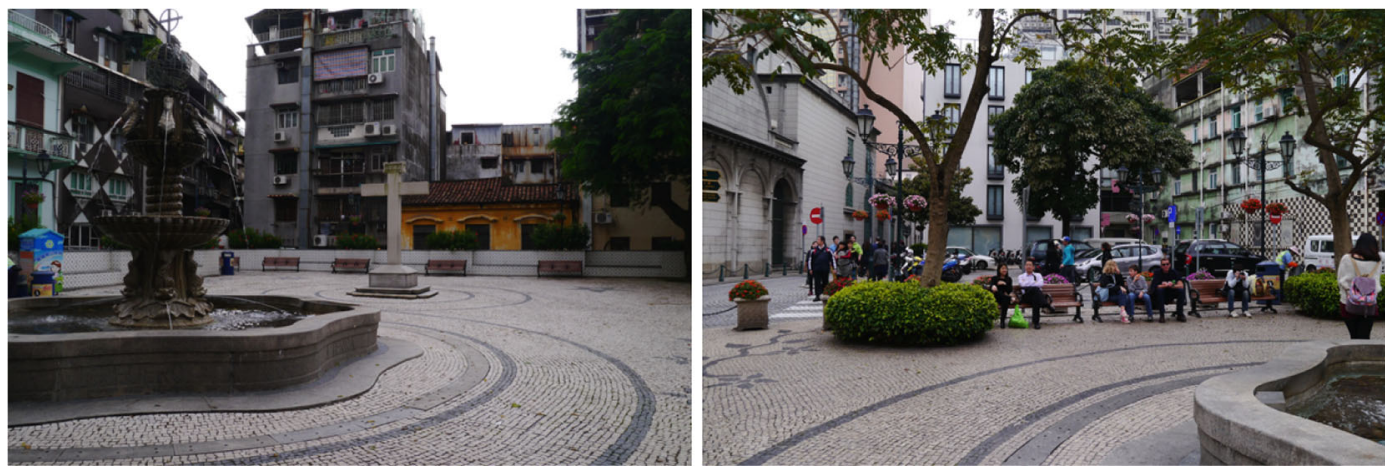

Figure 8: Left Urban sculpture in Cathedral Square, a fountain of classical design and a cross, which is supposed to be re-installed at an incorrect location (2013). Right Benches in tree shades attract passers-by (2014).

Source: Photos by the authors.
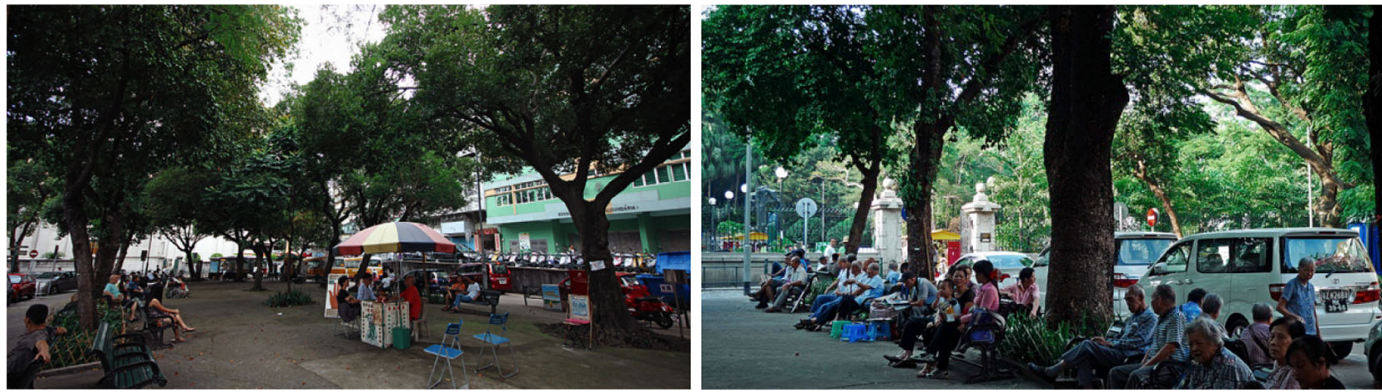

Figure 9: Camoes Square in 2012. Left Physiognomy stall. Right Elderly people taking a rest. Source: La Série Originale blog (2012).

rehabilitation of Cathedral Square. However, IC also expressed concerns about its historic aspects including the landscape and green areas, and in particular, authenticity issue in the location of the cross-shaped sculpture (Figure 8, left).

The Cathedral Square Redevelopment Project was not solely about improving the urban streetscape; rather, it was an integrated approach that included the beautification of urban areas while upgrading their functionality. It comprised continual incremental sub-projects. For instance, the square's pavement was changed to match that of Senado Square - black and white cobblestones that give a strong indication of the Portuguese influence on the city's built environment.

Removal of much of the parking space returned the leisurely atmosphere to the square, but whether people are willing to stay and spend some time there largely depends on the urban furniture. The creation of spacious open ground limits seating (Figure 8, right) as well as limiting tree planting to provide shade. A wall seat has been constructed in addition to ordinary benches, but it has proven to be a rather unpopular choice for sitting.

\section{Camoes Square}

Camoes Square (Praça de Luís de Camões) is situated in the foreground of Camoes Park, in Macao's St. Anthony's Parish. It is the last square in the World Heritage List to be part of the series of government efforts to revitalize and beautify the historic centre, and is both a buffer zone for vehicular traffic and an extension of the park per se. The walls of the park and the streets in front of it, together with other adjacent buildings, clearly define the boundary of Camoes Square.

In 2010, IACM implemented the Camoes Square Rehabilitation Project, after similar projects in other squares in the historic centre. At that time, some of the issues addressed included garbage bins, bus terminal, and the road which was running close to the park's entrance and thus destroying the central axis.

The Camoes Square Rehabilitation Project grew out of the necessity to integrate squares and monumental buildings into an organic yet historic centre that satisfies the needs of both residents and tourists. As a popular spot used by residents for leisure (Figure 9), Camoes Square required a rehabilitation approach 

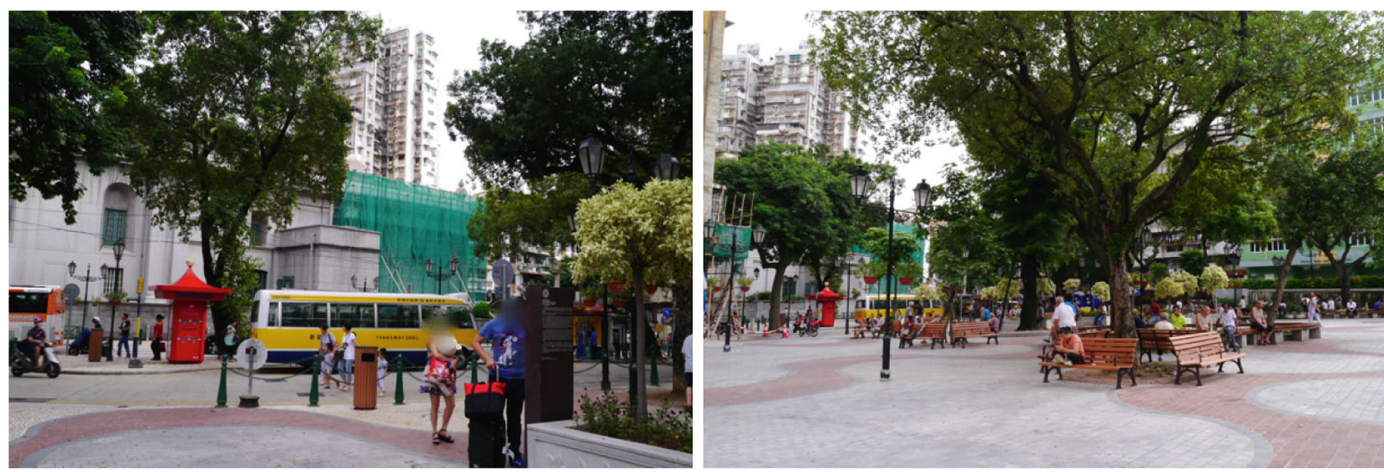

Figure 10: Camoes Square in 2013. Left Renovated bus terminal and cobblestone-paved square. Right Leisure space in place of parking space.

Source: Photos by the authors.

Table 2: Comparison of revitalization initiatives in three key squares since World Heritage inscription

\begin{tabular}{|c|c|c|c|}
\hline & Lilau Square & Cathedral Square & Camoes Square \\
\hline Area & $\begin{array}{l}\text { Corridor from Barra Square to St. } \\
\text { Augustine's Square, with Lilau } \\
\text { Square located at mid point }\end{array}$ & $\begin{array}{l}\text { Open space in front of the Cathedral and } \\
\text { the connecting streets (Travessa da Sé, } \\
\text { Travessa do Bispo and Travessa de S. } \\
\text { Domingos) }\end{array}$ & $\begin{array}{l}\text { Open space outside the gate of } \\
\text { Camoes Park and adjacent to } \\
\text { St. Anthony's Square }\end{array}$ \\
\hline $\begin{array}{l}\text { Urban } \\
\text { character }\end{array}$ & Residential, semi-private & Religious, open & Residential, open \\
\hline $\begin{array}{l}\text { Related } \\
\text { project } \\
\text { (year) }\end{array}$ & $\begin{array}{l}\text { Beautification of Largo do Lilau } \\
\text { (2009) } \\
\text { Sidewalk beautification from Rua de } \\
\text { S. Lourenço to Largo do Santo } \\
\text { Agostinho }(2009,2011)\end{array}$ & $\begin{array}{l}\text { Beautification of Largo da Sé (2004) } \\
\text { Installation of electromechanical devices } \\
\text { of the fountain (2004) } \\
\text { Beautification of the fences and stone } \\
\text { pillars (2004) } \\
\text { Placing decorative lines (2005) } \\
\text { Replacement of the statue in the fountain } \\
\text { (2005) } \\
\text { Wall renovation and maintenance (2006) } \\
\text { Repair to the water fountain, flower beds, } \\
\text { and walls (2009) }\end{array}$ & $\begin{array}{l}\text { Improvement of Largo de Santo } \\
\text { António (2008) } \\
\text { Reorganization of a section of } \\
\text { Praça de Luís de Camões and } \\
\text { in Travessa da Gruta (2008) }\end{array}$ \\
\hline $\begin{array}{l}\text { Guiding } \\
\text { concept }\end{array}$ & $\begin{array}{l}\text { Myth of the "Lilau" spring } \\
\text { Rua Direita (main street) }\end{array}$ & $\begin{array}{l}\text { The Cathedral as the focal point } \\
\text { Authenticity in the square layout }\end{array}$ & $\begin{array}{l}\text { Visual continuity in the Historic } \\
\text { C }\end{array}$ \\
\hline $\begin{array}{l}\text { Improvement } \\
\text { type }\end{array}$ & $\begin{array}{l}\text { Repaving } \\
\text { Gazebo vending stall }\end{array}$ & $\begin{array}{l}\text { Repaving } \\
\text { Relocation of car parking spaces } \\
\text { Decoration and seating }\end{array}$ & $\begin{array}{l}\text { Repaving } \\
\text { Classical style urban furniture }\end{array}$ \\
\hline $\begin{array}{l}\text { Inclusiveness } \\
\text { of various } \\
\text { urban } \\
\text { components }\end{array}$ & $\begin{array}{l}\text { Illegal staircase in front of a } \\
\text { residential buildings removed } \\
\text { Portuguese-style residences at Lilau } \\
\text { Square are still left vacant, despite } \\
\text { being the key elements of urban } \\
\text { revitalization }\end{array}$ & $\begin{array}{l}\text { The walls of the Cathedral is also } \\
\text { renovated accordingly. }\end{array}$ & $\begin{array}{l}\text { More of a standalone urban } \\
\text { space than a happening node, } \\
\text { despite its proximity to } \\
\text { different land uses }\end{array}$ \\
\hline
\end{tabular}

that provided a comfortable place for rest and enlarged its capacity for an increase in the number of visitors. Repaving was conducted in the square to achieve visual unity through the representative wavy pattern. Urban furniture including items of classic design was also installed (Figure 10). In regard to one of the most important criteria for rehabilitating Camoes Square, i.e., to enhance its functionality without detracting from the spirit of the place, it is evident that the previous vitality diminished during the one-off revamp project, despite the government's intention to create a living urban relic recharged by the daily use of local residents.

\section{An architectural ensemble struggling to regain its bygone vitality}

As summarized in Table 2, one focus of the beautification of historic urban fabric is the 

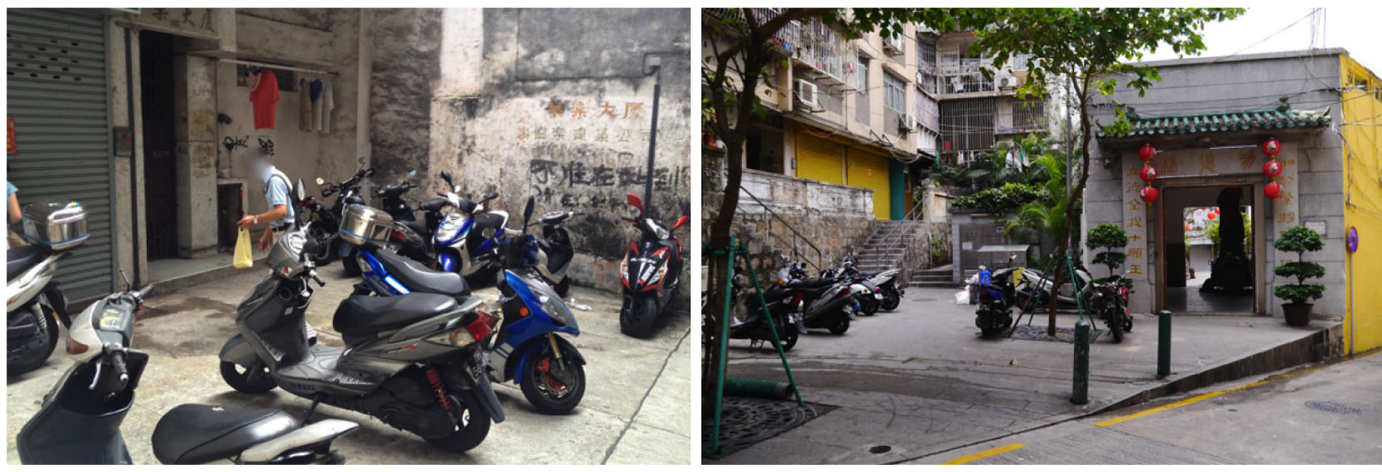

Figure 11: Residual open spaces in Macao, formed by widening parts of streets and occupied by motorcycle parking. Left Rua da Casa Forte. Right Rua de S. Jose.

Source: Photos by the authors.

cobblestone pavement, which is a key element of the visually striking and continuous pedestrian network and assists in the dispersal of tourists within the densely populated historic centre. In addition, a gazebo vending stall has been set up in the square - a type of urban furniture-cumamenity that also appears in St. Augustine's Square. This locality-sensitive practice, rather than monotonous, reflects the style of IACM's efforts in the contextual interpretation of the local squares' value such that new elements are introduced in harmony with the existing surroundings. However, it is still unclear whether conserving the aesthetic significance of the setting actions has had beneficial results; the vicinity still lacks vitality since the adjacent traditional residential buildings are vacant, which suggests there are other aspects of greater concern to the residents or users themselves.

Small-scale pocket parks, which employ a similar approach of applying the chintei tradition in a more comprehensive yet less noticeable manner, have been created by improving the public space through street widening or extension, and utilizing an open area in front of buildings. The beautification of the streets that pass Lilau Square includes what are believed to be Largo do Seminario St. Jose and Largo de St. Lourenço (Korenaga, 2006), despite the lack of street nameplates. A square's inherent character, which is connected to the architecture surrounding it, is reflected in its name. Therefore, the removal of a square's original name is an act of indistinguishable integration that detracts from its uniqueness and visibility. Against this backdrop, the significance manifests itself of applying the chintei approach toward an integrated pedestrian network in an urban setting of cultural heritage.

\section{Conclusion}

Macao's colonial history has endowed it with a rich cultural and urban heritage in its built environment that requires a locality-sensitive approach to conservation and revitalization. The paper focuses on a highly localized form of the square - chintei. Verification of the squares' nomenclature and location (whether in or outside the old city), an examination of their configuration, and their relationship with the elements within them (whether there is any focal point) reveals that squares' spatial and cultural characteristics are inseparable from each other. IC's highlighting of historic squares during the application for UNESCO inscription demonstrates a great awareness of their cultural significance. Subsequent beautification initiatives by IACM are an attempt to find a balance between heritage conservation and tourism development. Case studies of key historic squares have also examined the degree of inclusion of various urban components, which may vary greatly.

The duality of squares can be understood as a product of their status as public spaces that are susceptible to change, either by the government or by the community, and of their possession of an identity that cannot be separated from the monuments or historic buildings around them. The movement of Macao's commercial center in different periods is well documented in a study of the morphological evolution of Macao's traffic network that uses Space Syntax analysis, supplemented by a sociological analysis (Feng et al, 2012). This contributes to a more complete understanding of squares, especially as part of the pedestrian network and even as part of a larger urban context, as it is contended in this paper that the 
intrinsic identity of these historic squares lies in their street pattern and proximity to peripheral buildings or other land use. This in turn enables the identification of residual spaces (Figure 11) with substantial potential in a similar urban setting.

The collision of heritage conservation, facility enhancement, and tourism development has resulted in a contemporary stance to place-making; however, issues still remain about how to maintain Macao's unique urban identity, which projects "a phantasmagoria of diverse hybrid progeny as one aspect of the colonial legacies" (Cheng, 2002). Tourism development may increase the encroachment on the unique urban fabric and necessitate the dispersion of tourists by means of urban revitalization in the local squares and associated streets and buildings. However, as seen in the recent refurbishment of Lilau Square, Cathedral Square, and Camoes Square, although the chintei approach is generally successful in beautifying the historic centre, it is a process of trial and error, and changes in the functional and perceptual dimensions should both be treated carefully. Be it resident-oriented or tourist-oriented, a universal sense of place is achievable only on the condition that the urban fabric welcomes change, but with a site-specific sensibility or discretion that achieves a balance between the cultural identity and pedestrian amenities. To this end, a deeper analogy can be drawn from the beyond-imagination glass blocks surrounding the old town, to the immiscibility of the place-making currents that converge in Macao's squares. The built environment is closely associated with the social and administrative systems. The revision of the Land Law, the promulgation of Macao's first Urban Planning Law, and the Heritage Conservation Law on March 1, 2014, the new reclamation areas, the construction of Hong Kong-ZhuhaiMacao Bridge, and the handover of jurisdiction over a marine area of $85 \mathrm{~km}^{2}$ on Macao SAR's 16th anniversary in 2015, all suggest a new phase of urbanism for Macao. The historic squares and residual spaces are likely to play a more active role in fine-tuning Macao's urban fabric in the future.

\section{Acknowledgements}

The authors thank Francisco Vizeu Pinheiro for his thoughtful and insightful contributions to this study.

\section{Notes}

1 Timeframe of the transfer of sovereignty over Macao was set in the Joint Declaration of China and Portugal on the question of Macao, signed at Beijing on April 13, 1987, and registered on March 22, 1988.

2 The transliteration of the two Chinese terms are based on their Cantonese pronunciation. Both terms denote squares but chintei is regarded as a Cantonese dialect term, usage of which is especially prevalent in Macao.

3 China's top legislature - the National People's Congress approved the 12th Five-Year Plan (FYP) in March 2011, and mentioned the long-term prosperity and stability of Hong Kong and Macao. Supportive attitude was shown toward Macao's becoming a global tourism and leisure center and deepening its cooperative relationship with Hong Kong and Guangdong Province.

4 Stated as one of the main objectives in the chapter of Civil Construction and Sewerage Maintenance in the annual reports of $\operatorname{IACM}(2009,2010,2011,2012)$, https: / /www.iacm.gov.mo/ c/report/thumbnail/(accessed August 16, 2015).

5 Decree DEC/34/76/M "Matters of the Classification of Macao's Artistic Heritage", Public Law 32, Gazette of Macao (1976): 1100.

6 Decree DEC/83/92/M "Revision of the List of Relics, Architectural Ensembles and Scenic Spots Attached to June 30 Decree no.56/84/M and May 31 Decree no.90/89/M", Public Law 52, Gazette of Macao (1992): 6367.

7 The survey is conducted at ten historical yet tourist spots, and the number of interviewee is around 100 each. Positive aspects regarding what people like about such places are preset as following: ambience/environment, cleanness, harmony, quietness/peace, spaciousness/comfort, green area/landscape, photographic attractiveness, PortugueseChinese mix of cultures. On the other hand, there are also downside comments addressing the lack of signage/directory, toilets, shelters; and too much construction and traffic.

8 Cathedral Square, http://worldvisitguide.com/salle/ MS05024.html (accessed November 6, 2013).

\section{References}

Cheng, C.M.B. (2002) Cultural significance: The identity of Macao. Review of Culture 4: 52-63.

Duncan, C. (1987) Development of Macao's city landscape. In R.D. Cremer (ed.) Macao: City of Commerce and Culture. Hong Kong: UEA Press.

Edmonds, R.L. and Yee, H.S. (1999) Macao: From Portuguese autonomous territory to Chinese Special Administrative Region. The China Quarterly 160: 801-817.

Feng, C., Wang, H. and Rao, X. (2012) The morphological evolution of Macau. Paper presented at the Eighth International Space Syntax Symposium, Chile.

Figueira, F. (1988) Foreword to Macao Cultural Heritage. In: C. Marreiros (ed.) Macao Cultural Heritage. Macao: Instituto Cultural.

Hayden, D. (1995) Place memory and urban preservation. In: D. Hayden (ed.) The Power of Place: Urban Landscapes as Public History (Vol, hard). Cambridge, MA: MIT Press.

Huang, W. (2002) Aomen jiuchengqu chengshi xingtai chutan [A preliminary study of the urban form of the old district of Macao]. Master's thesis. Beijing: Tsinghua University. 
Huang, Y. (2012) Yuanrong hexie: aomen yuanxingdi de wenhua jiedu [The great harmony of cultures: decoding the culture of the roundabouts in Macao]. Journal of Macao Studies (65): 140-147.

Huang, Y. (2007) Aomen yuyan yanjiu [Study of the Languages in Macao]. Beijing: Commercial Press.

IACM (Civic and Municipal Affairs Bureau of Macao). (2015) Aomen jiujie wangshi: huawangtangqu [Stories About Old Streets of Macao: Parish of Santo António]. Macao: IACM.

IACM (Civic and Municipal Affairs Bureau of Macao). (2013a) Aomen jiujie wangshi: huadimatangqu [Stories About Old Streets of Macao: Parish of Nossa Senhora de Fátima]. Macao: IACM.

IACM (Civic and Municipal Affairs Bureau of Macao). (2013b) Aomen jiujie wangshi: wangdetangqu [Stories About Old Streets of Macao: Parish of São Lázaro]. Macao: IACM.

IACM (Civic and Municipal Affairs Bureau of Macao). (2013c) Aomen jiujie wangshi: fengshuntangqu [Stories About Old Streets of Macao: Parish of São Lourenço]. Macao: IACM.

IACM (Civic and Municipal Affairs Bureau of Macao). (2013d) Aomen jiujie wangshi: datangqu [Stories About Old Streets of Macao: Parish of Sé]. Macao: IACM.

IC (Cultural Affairs Bureau of Macao SAR). (2001) Start-up of Macao's application for UNESCO World Heritage and release ceremony of Culture of metropolis in Macao-An international symposium on cultural heritage. http://www.wh. mo/wh/NewsDC.asp?nid=3835, accessed 17 April 2013.

ICOMOS. (2005) ICOMOS evaluation. In the Advisory Body Evaluation of China's application, Macao, no. 1110, ed. UNESCO.

ICOMOS. (1987) Charter for the conservation of historic towns and urban areas. Adopted by ICOMOS General Assembly in Washington, DC, October 1987.

Kato, G. (2003) Makao ni okeru fukurokouji kara mita toshikankyō wo keiseisuru shisutemu (sono ichi) [System for urban environment seen in the dead end streets of Macao]. AIJ Gakujutsu Kōen Kōgaishū F-2 Kenchiku-Rekishi Ishō 2003: 393-394.

Korenaga, M. (2006) Makao kyūshigai ni okeru zenchi wo chūshin tosita yōto to kōbai no renzokusei [Continuity of uses and inclination around chin dei in the old district of Macao]. AIJ Keikaku-kei Ronbun-shū 599: 111-117.

Korenaga, M. (2003) Makao ni okeru hiroba wo chūshin toshita kūkan to yōto no renzokusei: sono ichi [Continuity of space and use in the open spaces of Macao, part 1]. Gakujutsu Kōen Kōgaishū F-2 Kenchiku-Rekishi Ishō 2003(07/30): 389-390.

La Série Orignale blog. (2012) Good bye, Camoes Square, posted on September 22, 2012. http://blog.billyau.com/ posts/2047, accessed 1 June 2015.

Li, C. (2007) Xunzhao Aomen-Li Chaoyong Haojiang jiuying sheying zuopinji [Visit to the Past of Macao-Photograghs by Li Chaohong]. Macao: Macao Museum of Art.

Li, P. (2006) Aomen gujin [Macao Then and Now]. New 1st Ed. Originally published in 1986. Hong Kong: Joint Publishing.

Lin, Y. (2004) Aomen qiandi kongjian [Chintei space in Macao]. Reivew of Culture. 2004(53): 1-36.

Lotus TV. (2014) Ducheng bian ducheng, xiuxian bian zouji, diandi? [City of gaming becoming city of congestion, leisure becoming fleeing. What do you think?], an episode in Call in Macao, aired on February 11, 2014.

Lotus TV. (2013) Bibaoguan!! ziyouxing lingdan bian duyao? jiuming [Border gate overcrowded! Indivisual Visit Scheme from antidote to poison? Help], an episode in Call in Macao, aired on February 27, 2013.
Lou, A. (2013) Former site of the Kun Iik fireworks company: The vanished fireworks industry. http://memoryMacao. blogspot.sg/2013/08/blog-post_11.html, accessed 26 August 2014.

Macao SAR (Special Administrative Region). (2005). Supplementary document to "the historic monuments of Macao".

Macao SAR (Special Administrative Region). (2004) The Historic monuments of Macao. Application to UNESCO for inscription on the World Heritage List by Macao SAR, formally submitted by the State Administration of Cultural Heritage of PRC.

Macao Today. (2009) Yapojing mubei zu longquan xie'e zhiji. Macao Today, 16 April 2009.

Matsuda, T. (2005) Makao kyūshigai no jūkankyō wo keisei suru fukurokōji no dankai kōsei [Hierarchical spatial composition of dead end streets for residential environmental in the old district of Macao]. AIJ Keikaku-kei Ronbun-shū 593: 1-7.

Nuñez, C.G. (1999) Macao Streets. Fang, W. (trans.) Hong Kong: Oxford University Press.

Pimonsathean, Y. (2004) Current issues concerning adaptive reuse in the conversation of urban cultural heritage. Paper presented at The Conservation of Urban Heritage: Macao Vision, Macao.

Pinheiro, F.V. and Wan, P. (2007) Urban planning practices and scenarios for Macao development. Paper presented at the 12th Real Estate Society Annual Conference, University of Macao.

Relph, E. (1976) Place and Placelessness. London: Pion.

Rykwert, J. (2002) The Seduction of Place: The History and Future of the City. New York: Vintage Books.

Simpson, T. (2013) Scintillant cities: glass architecture, finance capital, and the fictions of Macao's enclave urbanism. Theory, Culture $\mathcal{E}$ Society (October 10).

So, S. (2012) Attracting divergent segments to a destination: Assessing segment compatibility by activities sought-a case study of Macao. Journal of Vacation Marketing 18(4): 341.

Tan, X. (2009) Aomen chengqiang yu baolei paotai [Macao's City Walls and Fortresses], Aomen zhishi congshu [Collection of Macao Knowledge]. Hong Kong: Joint Publishing.

Tan, Z. (2011) Aomen de wenhua yichan baohu: wenti, zhengzhi yu zhengce [Cultural Heritage Conservation in Macao: Issues, Politics and Policies]. Macao: Macao Heritage Ambassadors Association.

Tiesdell, S., Oc, T. and Heath, T. (1996) Revitalizing historic urban quarters. New York: Architectural Press.

Tong, Q. (2005) Aomen chengshi huanjing yu wenmai yanjiu [Research on the Urban Environment and Context of Macao City]. Nanjing: Southeast University.

Tuan, Y.F. (1977) Space and Place: The Perspective of Experience. University of Minnesota Press.

UNESCO. (2005) Decisions of the 29th session of the world heritage committee. Paris: WHC-05/29.COM/22.

Va Kio Daily. (2009) Gangding zhi mage wuxian shiyi fengqing. Va Kio Daily, 31 January 2009.

$\mathrm{Xu}, \mathrm{Z}$. (2009) Aomen zongjiao jianzhu [Religious Architecture in Macao]. Beijing: China Electric Power Press.

Xue, F. (2013) Macao Through 500 Years (English Version). Singapore: Silkroad Press/Enrich Professional Publishing.

Yan, Z. (2006) Yige haifeng chuilai de chengshi: zaogi Aomen chengshi fazhanshi yanjiu. Guangzhou: Guangdong People's Publishing House.

Zhang, M., Wei, Y. and Yu, Y. (2011) On life cycle of cultural heritage engineering tourism: A case study of Macao. Systems Engineering Procedia 1: 351-357. 